\title{
Offshore tele-veiledet ultralyd
}

Victoria Vatsvåg

Stipendiat ved Helsefakultetet, avdeling for kvalitet og helseteknologi, Universitetet $i$ Stavanger

Ultralyd er svært brukeravhengig, det krever lang og grundig opplæring før man er i stand til å utføre undersøkelser med god diagnostisk verdi [1]. Mangel på tilstrekkelig undervisning og trening fremstår som en begrensning for utbredt bruk av denne teknologien [2]. Tele-veiledet ultralyd er en prosedyre som kobler eksperter med nybegynnere gjennom ulike typer kommunikasjons- og nettverksteknologier, med det overordnede målet å føre spesialisthelsetjenesten nærmere pasienter som er langt unna sykehus [3]. Et eksempel på et fjerntliggende sted med begrenset tilgang på avansert diagnostikk er en offshore oljeplattform.
I denne studien ønsket vi å gjøre følgende:

- Teste om telekommunikasjonsteknologien og nettverk tilgjengelig på en oljeplattform støtter sanntidsoverføring av ultralydbilder.

- Teste om en lege på land er i stand til å veilede en utrent ultralydbruker (sykepleier) i å utføre fokuserte undersøkelser av lunger, hjertet og abdomen.

- Analysere ultralydvideoer og bilder tatt av den utrente ultralydbrukeren under tele-veiledning for å avgjøre om kvaliteten er god nok til å ta behandlingsbeslutninger.

En offshoresykepleier uten tidligere ultralyderfaring be rekruttert til studien. På plattformens hospital ble en ultralydmaskin koblet til et eksisterende videokonferansesystem ( $\triangleright$ Fig. 1). Videre ble det rekruttert 37 frivillige offshorearbeidere som skanne- modeller. Sykepleieren ble veiledet av en lege på land til å utføre fokuserte ultralydundersøkelser av hjerte, lunge og abdomen. Stillbilder og video ble lagret underveis i tillegg til registrering av skannetid per undersøkelse.

Bildematerialet ble analysert av en uavhengig ekspertgruppe og scoret på en fempunkts skala ( 1 = dårlig bildekvalitet, 2 = redusert bildekvalitet, 3 = suboptimal bildekvalitet, 4 = akseptabel bildekvalitet, $5=$ optimal bildekvalitet). En score på 3 eller høyrer ble definert som tilstrekkelig kvalitet for å vurdere relevant anatomi og trekke ut klinisk informasjon.

Studien vår viser at det er gjennomførbart å bruke eksisterende telekommunikasjonssystemer og nettverk på en oljeplattform til å strømme ultralydbilder i sanntid. Vide-

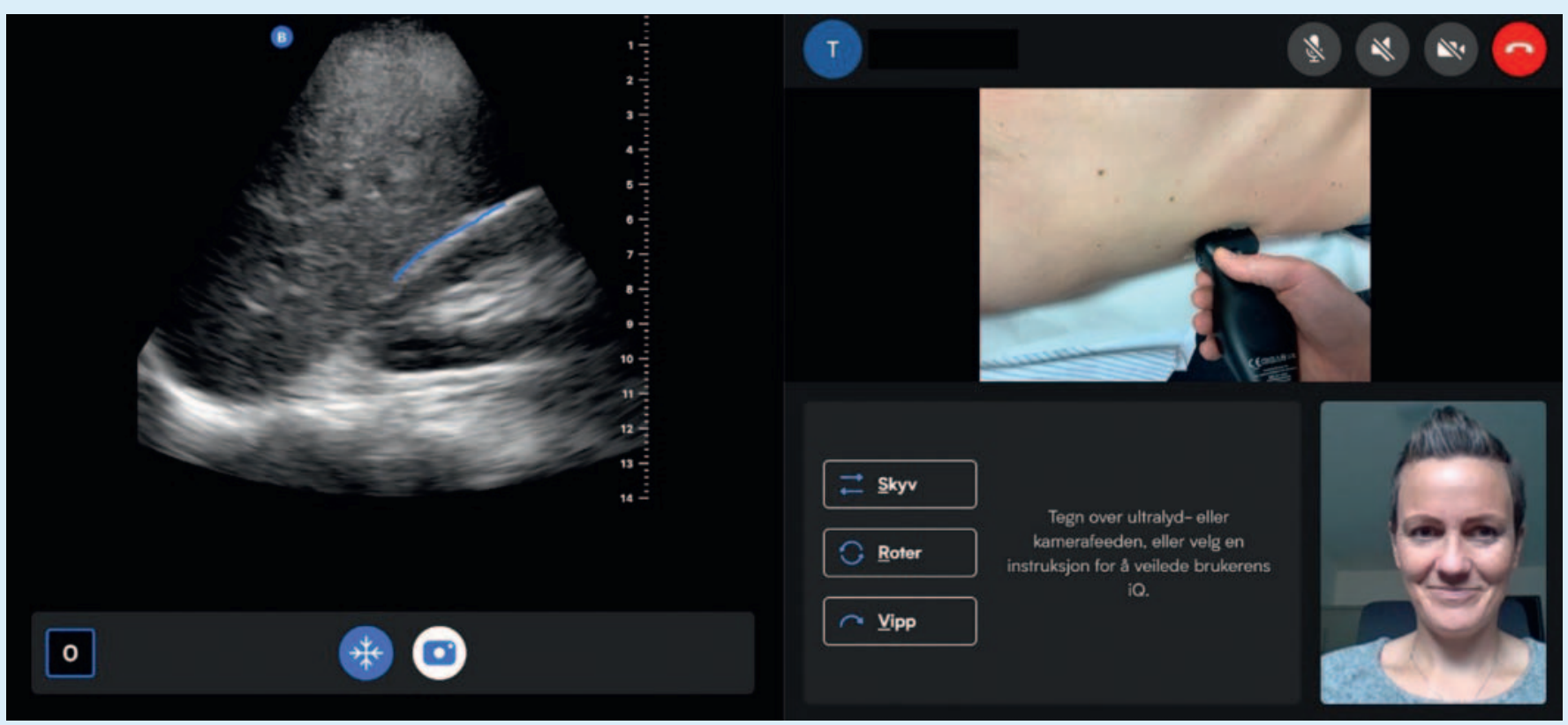

- Fig. 1 Tele-veiledet ultralyd kan utføres ved å koble et ultralydapparat opp mot telekommunikasjonssystem og nettverk, men det finnes apparater som har integrert videokonferansefunksjon. Butterfly $\mathrm{QQ}^{\mathrm{TM}}$ er en ultralydprobe som kobles til nettbrett eller telefon og gir brukeren mulighet til å ringe opp en ekstern person for veiledning. Bildet over viser veileder sin skjerm som fra sin side kan se både seg selv, pasienten og ultralydbildet. Foto: Victoria Vatsvåg. 
re ser vi at det er fullt mulig å tele-veilede noen uten ultralyderfaring i å utføre undersøkelser med høy diagnostisk verdi.

Denne studien (studie 1) er en del av et doktorgradsarbeid som ser på forskjellige aspekter ved tele-veiledet ultralyd. Doktorgradsarbeidet vil videre se på tele-veiledet ultralyd som undervisningsmetode (studie 2) og klinisk nytteverdi ved å implementere bruk av ultralyd i fjerntliggende områder (studie 3).
Studie 1 er allerede publisert i tidsskriftet The Ultrasound Journal [4], mens studie 2 og 3 forventes publisert i 2021 og 2023.

\section{References}

[1] Carbone M, Ferrari V, Marconi M et al. A teleultrasonographic platform to collect specialist second opinion in less specialized hospitals. Updates Surg 2018; 70 (3): 407-413
[2] Biegler N, McBeth PB, Tiruta C et al. The feasibility of nurse practitioner-performed, telementored lung telesonography with remote physician guidance - "a remote virtual mentor". Crit Ultrasound J 2013; 5 (1): 5

[3] McBeth PB, Crawford I, Blaivas M et al. Simple, almost anywhere, with almost anyone: remote low-cost telementored resuscitative lung ultrasound. J Trauma 2011; 71 (6): 1528-1535

[4] Vatsvag V, Todnem K, Naesheim T et al. Offshore telementored ultrasound: a quality assessment study. Ultrasound J 2020; 12 (1): 33 